\title{
Evaluasi Penempatan Pegawai Pada Badan Kepegawaian Dan Pengembangan Sumber Daya Manusia Kabupaten Merauke
}

\author{
Maria Margareta Reginaldis \\ Ilmu Administrasi Publik \\ Sekolah Tinggi Ilmu Administrasi Karya Dharma Merauke \\ Email; reginaldis323@gmail.com \\ Johanis Ohoiledyaan \\ Ilmu Administrasi Publik \\ Sekolah Tinggi Ilmu Administrasi Karya Dharma Merauke
}

Received: 26 September 2020; Revised: 09 Oktober 2020; Accepted : 15 November 2020;

Published : December 2020; Available online : December 2020.

\begin{abstract}
This study aims to determine (1) employee placement in accordance with the evaluation criteria at the Merauke Regency Personnel and Human Resources Development Agency, (2) the principles of assigning employees to the Merauke Regency Personnel and Human Resources Development Agency, (3) challenges in placement employees at the Merauke Regency Civil Service and Human Resources Development Agency. This research is a qualitative descriptive study. The research informants were the Head of the Personnel and Human Resources Development Agency of Merauke Regency, the Secretary of the Agency, the Head of the Personnel Administration, the Head of the Program and Evaluation Subdivision. The data collection techniques used were observation, interview and documentation. Data analysis uses the steps of data collection, data reduction, data presentation, and drawing conclusions. The results showed that the implementation of the evaluation of the placement of employees according to the evaluation criteria and placement principles was optimal and also not fully optimal, because there were still some obstacles, however, there were strategic steps taken so that the problem could be resolved. There are challenges in implementing employee placement, however these challenges are handled wisely and can be resolved immediately. In principle, the Merauke Regency Personnel and Human Resources Development Agency has taken strategic steps in dealing with existing problems and constraints so that the achievement of organizational goals can be achieved, in accordance with the programs that have been set.
\end{abstract}

Keywords: Evaluation, Employee Placement, Personnel Board and Human Resources Development in Merauke Regency 


\section{Pendahuluan}

Perbaikan kinerja birokrasi dalam memberikan pelayanan kepada publik dan untuk meningkatnya kinerja pegawai pada suatu organisasi, maka diperlukan evaluasi secara keseluruhan sehingga dapat meningkatkan daya saing Aparatur Sipil Negara (ASN) dalam organisasi tersebut dalam rangka peningkatan pelayanan prima kepada publik, dalam hal evaluasi penempatan pegawai.

Dalam pelaksanaan tugasnya Pegawai Negeri berkewajiban untuk tetap menjaga persatuan dan kesatuan bangsa serta melaksanakan tugasnya secara profesional dan bertanggung jawab dalam menyelesaikan tugas pemerintah dan pembanguan serta bersih dan bebas dari korupsi, kolusi dan nepotisme, seperti yang termuat dalam Undang - Undang Nomor 43 Tahun 1999 Bab II pasal 3 ayat 1 tentang pokok pokok Kepegawaian. menyatakan bahwa : Pegawai Negeri berkedudukan sebagai unsur aparatur negara yang bertugas untuk memberikan pelayanan kepada masyarakat secara profesional, jujur, adil, dan merata dalam penyelenggaraan tugas negara, pemerintah dan pembangunan.

Pegawai memiliki peran yang utama dalam setiap kegiatan organisasi, karena pegawai perencana, pelaksana dan penentu terwujudnya sistem organisasi, sehingga tujuan organisasi akan lebih mudah dicapai apabila pegawai ditempatkan pada posisi sesuai dengan kompetensi yang dimiliki, oleh sebab itu pegawai memiliki peran sentral dalam kelangsungan organisasi, sehingga hal yang sangat perlu diperhatikan adalah penempatan pegawai dalam suatu organisasi.

Penempatan

pegawai

bertujuan untuk menempatkan sumber daya manusia yang tepat pada jabatan yang sesuai dengan minat dan kemampuannya sehingga prestasi kerja dapat meningkat, maka pengelolaan sumber daya manusia harus dilakukan secara professional agar terwujud keseimbangan antara kebutuhan akan kemampuan sebagai sumber daya manusia dengan tuntutan organisasi, dimana keseimbangan tersebut merupakan kunci utama dalam organisasi sehingga organisasi dapat berkembang secara produktif.

Hal ini akan membawa suatu organisasi pada suatu hasil kerja yang optimal karena terdapat adanya korelasi yang positif antara penempatan pegawai dengan produktifitas kerja.

Penempatan pegawai penting diperhatikan, karena salah 
menempatkan pegawai akan menimbulkan penurunan prestasi kerja, kebosanan, menurunnya gairah kerja, dan sebagainya.

$$
\text { Dalam prinsip-prinsip }
$$

penempatan pegawai negeri hendaknya sebelum benar-benar membutuhkan tenaga kerja, dianalisa secara fungsi dan tugas yang ada, sehingga benar - benar organisasi membutuhkan pengisian tenaga sesuai untuk setiap fungsi dan tugas tersebut. Penempatan pegawai seharusnya terencana dan tertata dengan baik agar memberikan kepuasan kerja bagi pegawai bahkan memberikan motivasi untuk meningkatkan prestasi kerja. Begitu juga dengan Pengisian jabatan sebaiknya tidak dilakukan semata-mata karena meneruskan tradisi atau budaya dan dikarenakan kedekatannya pada pimpinan maka akan sulit untuk membawa perubahan bagi organisasi. Sedangkan pemimpin yang tepat dan terlatih dengan baik akan membawa organisasi pada pencapaian tujuan. Pemimpin yang berkualitas memiliki strategi untuk mencapai keberhasilan organisasi serta mampu mencegah penyimpangan dalam organisasi.

Sebagaimana diamanatkan dalam Undang-undang Nomor 5 Tahun 2014 tentang Aparatur Sipil Negara
(ASN) bahwa setiap instansi pemerintah mengumumkan secara terbuka kepada masyarakat adanya kebutuhan jabatan untuk diisi dari calon ASN, dan setiap warga Negara Indonesia mempunyai kesempatan yang sama untuk melamar menjadi ASN setelah memenuhi persyaratan.

Dalam fenomena yang terjadi di instansi Pemerintahan, ditemukan adanya ketidaksesuaian antara orang menduduki jabatan tertentu dengan kualiafikasi pekerjaan yang dibutuhkan. Dalam setiap merancang formasi perencanan pegawai, terdapat uraian jabatan dengan kualifikasi yang dimiliki calon pegawai, namun yang terjadi adalah pejabat yang berwenang kurang memperhatikan analisis jabatan dalam melakukan suatu penempatan pegawai sehingga hasil kerja organisasi kurang maksimal.

$\begin{array}{ccc} & \text { Keberhasilan suatu daerah } \\ \text { dalam } & \text { menjalankan } & \text { roda }\end{array}$
pemerintahannya sangat tergantung terutama pada Sumber Daya Manusia (SDM) yang menjabat sebagai aparatur negara karena mereka berperan penting dalam menggerakkan pemerintahan daerah serta mengelola sumber daya yang dimiliki daerah. Untuk menciptakan suatu pemerintahan daerah yang mumpuni, diperlukan pegawai yang 
berkualitas dan mempunyai kompetensi yang sesuai dengan jabatan yang diemban sehingga dapat melaksanakan tugasnya secara profesional dalam sistem kepegawaian Negara.

Badan Kepegawaian dan Pengembangan Sumber Daya Manusia Kabupaten Merauke mempunyai tugas pokok membantu Bupati Kabupaten Merauke dalam penyelenggaraan Pemerintah Daerah dibidang Kepegawaian dan Pengembangan Sumber Daya Manusia dan Pelatihan dalam hal ini sumber daya aparatur, berdasarkan tugas pokok tersebut pada Badan Kepegawaian dan Pengembangan Sumber Daya Manusia kabupaten Merauke diharapkan pegawainya memiliki kinerja yang baik, produktif, profesional dan bertanggung jawab terhadap pekerjaan yang dibebankan padanya sesuai dengan peraturan yang sudah ditetapkan.

Fenomena diatas adalah sebuah fenomena yang sering dijumpai pada Badan Kepegawaian dan Pengembangan Sumber Daya Manusia Kabupaten Merauke khususnya dalam penempatan pegawai antara lain : kriteria evalausi keefektifan belum sepenuhnya efektif, ketanggapan belum sepenunhnya pegawai tanggap pada uraian tugas dan tanggungjawab sehingga bisa mempengaruhi kinerja yang ada dan pada prinsip the right man on the right place belum sepenuhnya optimal, hal tersbeut disebabkan oleh kebijakan penempatan yang adalah kewenangan Badan Kepegawaian Negara (BKN), namun demikian fenomena tersebut disikapi dengan bijak oleh unsur pimpinan sehingga bisa dikatakan fenomena - fenomena tersebut bisa diatasi dengan kebijkan - kebijakan yang di ambil. Sehingga penulis tertarik untuk mengkaji fenomena tersebut lebih mendalam. Penulis ingin mengetahui dan mendeskripsikan penempatan pegawai sesuai dengan kriteria evaluasi pada Badan Kepegawaian dan Pengembangan Sumber Daya Manusia kabupaten Merauke, Untuk mengetahui dan mendeskrisikan prinsip - prinsip penempatan pegawai pada Badan Kepegawaian dan Pengembangan Sumber Daya Manusia kabupaten Merauke. Serta untuk mengetahui apa saja tantangan dalam penempatan pada Badan Kepegawaian dan Pengembangan Sumber Daya Manusia kabupaten Merauke .

\section{A. Kajian Pustaka}

\section{Kebijakan Publik}

Secara umum, istilah "kebijakan" atau "policy" digunakan untuk menunjuk perilaku seorang aktor ( 
pejabat, kelompok, maupun lembaga pemerintah) atau sejumlah aktor dalam suatu bidang kegiatan tertentu. Pengertian kebijakan seperti ini dapat digunakan dan relative memadai untuk keperluan pembicaraan-pembicaraan biasa, namun menjadi kurang memadai untukcpembicaraan-pembicaraan yang bersifat ilmiah dan sistematis menyangkut analisis kebijakan publik. Oleh karena itu, kita memerlukan batasan atau konsep kebijakan publik yang lebih tepat.

\section{Thomas R. Dye,}

Mengatakan bahwa pengertian kebijakan publik Merupakan segala sesuatu yang dikerjakan pemerintah, mengapa mereka melakukan, dan hasil yang membuat sebuah kehidupan bersama tampil berbeda.

Menurut pendapat, Carl Frederich Mengatakan bahwa pengertian kebijakan publik Merupakan serangkaian tindakan yang diusulkan seseorang, kelompok, atau pemerintah dalam suatu lingkungan tertentu, dengan ancaman dan peluang yang ada.

$$
\text { Pendapat lain menurut }
$$

David Easton, Mengatakan bahwa pengertian kebijakan publik merupakan pengaruh dan aktivitas pemerintah.

\section{Konsep Evaluasi Kebijakan} Publik
Evaluasi kebijakan publik merupakan salah satu tahapan dalam analisis kebijakan publik yang bertujuan untuk menilai secara keseluruhan bahwa suatu kebijakan publik yang akan, sedang dan sudah dilaksanakan itu berhasil mencapai tujuan, sasaran dan dampak secara optimal bagi kepentingan bersama.

Evaluasi kebijakan publik menurut Howlett and Ramesh (Zaenal, 2004 : 345) mendefinisikan sebagai suatu pengkajian secara sistematik, empiris terhadap akibat-akibat dari suatu kebijakan dan program pemerintah yang sedang berjalan dan kesesuaiannya dengan tujuan-tujuan yang hendak dicapai oleh kebijaksanaan tersebut.

Sedangkan Dunn (1998: 608) menyamakan evaluasi dengan penaksiran (appraisal), pemberian angka (rating) dan penilaian (assessment), katakata yang menyatakan usaha untuk menganalisis hasil kebijakan dalam arti satuan nilai. Dalam arti yang spesifik, evaluasi berkenaan dengan produksi informasi mengenai nilai atau manfaat hasil kebijakan. Sehingga tujuan evaluasi adalah untuk menilai secara keseluruhan pengaruh dan dampak pada akhir program, yang akan menjadi landasan untuk meningkatkan atau 
menyempurnakan kebijakan berkenaan dengan program atau kebijakan berikutnya. Sementara itu, Siagian (2005 : 45) mendefinisikan evaluasi sebagai proses pengukuran dan pembandingan dari hasil-hasil pekerjaan yang nyatanya dicapai dengan hasil-hasil yang seharusnya dicapai. Atau menurut Zainal (2004 : 347), evaluasi akan menghasilkan informasi yang bersifat penilaian dalam memenuhi kebutuhan, peluang dan atau memecahkan permasalahan.

Secara konseptual ada pandangan yang menyatakan bahwa evaluasi dapat dilakukan pada seluruh periode kegiatan, artinya dapat dilakukan pada saat kegiatan belum dilaksanakan, evaluasi pada saat kegiatan berlangsung dan setelah kegiatan dilaksanakan (Riyadi, 2003:268). Oleh karena itu berdasarkan pandanag tersebut, evaluasi dapat dibedakan menjadi : (1) Pra Evaluasi, yakni evaluasi yang dilakukan pada saat program belum berjalan atau beroperasi pada tahap perencanaan, (2) Evaluasi pada saat program tengah berjalan, yang dikenal dengan ongoing evaluation atau in operation evaluation, atau oleh Bintoro (1988:86) disebut juga dengan miidtern evaluation, (3) Evaluasi setelah program selesai atau setelah program berakhir.

3.

Pengertian Penempatan

Pegawai

Pengertian Pegawai Negeri menurut Pasal 1 ayat (1) Undang-undang No. 43 Tahun 1999, tentang Undangundang Pokok Kepegawaian adalah sebagai berikut :

"Pegawai Negeri adalah setiap warga Negara Republik Indonesia yang telah memenuhi syarat yang ditentukan, diangkat oleh pejabat yang berwenang dan diserahi tugas dalam suatu jabatan negeri, atau diserahi tugas negara lainnya, dan digaji berdasarkan peraturan perundang-undangan yang berlaku".

Sedangkan dalam Kamus Besar Bahasa Indonesia, pegawai negeri adalah : "pegawai pemerintah yang berada di luar politik, bertugas melaksanakan administrasi pemerintahan berdasarkan peraturan perundangundangan yang telah ditetapkan".

Dengan demikian, Aparatur atau Pegawai Pemerintah Daerah dapat didefinisikan sebagai alat kelengkapan pemda yang bertugas melaksanakan roda pemda sehari-hari, yang berada diluar politik, bertugas melaksanakan administrasi pemerintah di daerah dan 
mendapatkan imbalan (gaji) berdasarkan peraturan perundang-undangan yang telah ditetapkan.

$$
\text { Setelah memahami }
$$

pengertian pegawai negeri maka selanjutnya kita pahami tentang penempatan pegawai. Dalam menghasilkan sumber daya manusia yang terampil dan andal perlu adanya suatu perencanaan dalam menentukan pegawai yang akan mengisi pekerjaan yang ada dalam suatu instansi pemerintahan. Keberhasilan dalam pengadaan tenaga kerja terletak pada ketepatan dalam penempatan pegawai.

$$
\text { Proses penempatan }
$$

merupakan suatu proses yang sangat menentukan dalam mendapatkan pegawai yang kompeten yang dibutuhkan instansi, karena penempatan yang tepat dalam posisi jabatan yang tepat akan dapat membantu dalam mencapi tujuan yang diharapakan.

Berikut beberapa pendapat para ahli mengenai pengertian penempatan pegawai, antara lain sebagai berikut:

Menurut Marihot T. E. Hariandja (2005 : 156) penempatan pegawai adalah : penempatan merupakan proses penugasan/ pengisian jabatan atau penugasan kembali pegawai pada tugas/ jabatan baru atau jabatan yang berbeda.

Menurut Mathis \& Jackson (2006:262) penempatan pegawai adalah : menempatkan posisi seseeorang ke posisi pekerjaan yang tepat, seberapa baik seorang karyawan cocok dengan pekerjaanya akan mempengaruhi jumlah dan kualitas pekerjaan.

\section{Menurut B. Siswanto} Sastrohadiryo yang dikutip oleh Suwatno (2003:138) penempatan pegawai adalah : untuk menempatkan pegawai sebagai unsur pelakasana pekerjaan pada posisi yang sesuai dengan kemampuan, kecakapan dan keahliaanya.

Menurut Gomes (1998 : 120) penempatan pegawai adalah : merupakan serangkaian langkah kegiatan yang dilaksanakan untuk memutuskan apakah tepat atau tidaknya seseorang pegawai di tempatkan pada posisi tertentu yang ada di dalam organisasi.

\section{Menurut Rivai (Suwatno \&}

\section{Donni Juni Priansa, 2013:97)} mendefinisikan bahwa penempatan adalah : mengalokasikan para pegawai pada posisi kerja tertentu hal ini khusus terjadi pada karyawan baru.

Menurut Melayu S.P. Hasibuan (2008:32), Mengemukakan bahwa penempatan karyawan adalah : tindak 
lanjut dari seleksi, yaitu menempatkan calon karyawan yang diterima pada jabatan/pekerjaan yang dibutuhkannya dan sekaligus mendelegasikan authority kepada orang tersebut.

Menurut Veithzal Rivai dan Ella Jauvani Sagala (2009:198)

"Penempatan adalah penugasan kembali seorang karyawan kepada pekerjaan barunya".

Sedangkan menurut Sikula

(Tjuju Yuniarsih \& Suwatno, 2013 :

115) menyatakan bahwa penempatan adalah : menyesuaikan atau mencocokkan kualifikasi individu dengan tuntutan pekerjaan.

Selanjutnya menurut Mathis dan Jackson (Yuniarsih dan Suwatno, 2013:115) tentang penempatan adalah : penempatkan seseorang pada posisi yang tepat (fitting a person to the right job).

Menurut Veithzal Rivai dan Ella Jauvani Sagala $\quad$ (2009:198)

"Penempatan adalah penugasan kembali seorang karyawan kepada pekerjaan barunya".

Berdasarkan definisi yang yang dikemukakan oleh para ahli diatas, maka dapat kami simpulkan penempatan pegawai adalah : kegiatan mengalokasikan para pegawai pada posisi kerja tertentu yang sesuai dengan kemampuan, kecakapan, dan keahliannya guna untuk mencapai tujuan instansi tersebut.

Terdapat tiga jenis dari penempatan yaitu promosi, transfer dan demosi serta job-posting program.Berikut penjelasan tiga jenis penempatan :

\section{a) Promosi}

Promosi adalah pemindahan pegawai dari satu pekerjaan ke pekerjaan lain yang lebih tinggi dalam penggajian, tanggung jawab dan atau level.

b) Transfer dan Demosi

Transfer adalah pemindahan pegawai dari satu bidang tugas ke bidang lainnya yang tingkatannya hampir sama baik tingkat gaji, tanggung jawab, maupun tingkat strukturalnya.

Demosi adalah pemindahan pegawai dari satu posisi ke posisi lainnya yang lebih rendah tingkatannya, baik tingkat gaji, tanggung jawab, maupun tingkat strukturalnya.

c) Job-Posting Program Job-posting program adalah program yang memberikan informasi pada pegawai tentang lowongan kerja dan persyaratannya. Tujuan dari program ini adalah untuk memberikan dorongan bagi pegawai yang mencari promosi dan transfer serta membantu departemen di dalam mengisi jabatan internal. 
4.

Syarat

Syarat

Penempatan

\section{Menurut Sulistiyani \&}

Rosidah (2003:152) ada beberapa persyaratan penting yang harus dipenuhi dalam rangka penempatan pegawai, adapun persyaratan yang harus dipenuhi tersebut adalah sebagai berikut :

a) Informasi analisis jabatan yang memberikan deskripsi jabatan, spesialisasi jabatan dan standar prestasi yang seharusnya ada dalam setiap jabatan tersebut.

b) Rencana-rencana Sumber Daya Manusia yang akan memberikan manajer tentang tersedia tidaknya lowongan pegawai suatu instansi.

c) Keberhasilan fungsi rekrutmen yang akan menjamin manajer bahwa tersedia sekelompok orang yang akan dipilih.

Selanjutnya menurut Sastrohadiwiryo (Yuniarsih \& Suwatno, 2013:117) mengemukakan faktor-faktor yang perlu dipertimbangkan dalam menempatkan pegawai adalah sebagai berikut :

a)

Faktor

prestasi

Akademik

Prestasi akademik yang dimaksudkan adalah prestasi yang telah dicapai oleh pegawai selama mengikuti jenjang pendidikan SD sampai pendidikan terakhir, dipadukan dengan prestasi akademis yang diperoleh berdasarkan hasil seleksi yang telah dilakukan terhadap pegawai yang bersangkutan, sehingga hiharapkan memberikan masukan dalam menempatkan pegawai pada posisi yang tepat pula.

b)

Faktor pengalaman

Faktor pengalaman perlu mendapat pertimbangan karena ada kecenderungan, makin lama bekerja makin banyak pengalaman yang dimiliki dan sebaliknya makin singkat masa kerja, maka makin sedikit pengalaman yang diperoleh.

c)

Faktor kesehatan

fisik dan mental

Faktor ini juga tidak kalah pentingnya dengan faktor-faktor tersebut karena bila diabaikan dapat merugikan lembaga. Oleh karena itu terdapat tes kesehatan sebelum pegawai diterima.

d)

Faktor

status

perkawinan

Status perkawinan juga harus diperhatikan mengingat banyak hal merugikan bila tidak ikut dipertimbangkan, terutama bagi wanita sebaiknya ditempatkan pada lokasi atau kantor cabang di mana suaminya bertugas.

e) Faktor usia 
Dalam rangka menempatkan pegawai, faktor usia pada diri pegawai yang lulus pada seleksi, perlu mendapatkan pertimbangan. Hal ini dimaksudkan untuk menghindarkan rendahnya produktivitas kerja yang dihasilkan dari pegawai yang bersangkutan. Teori manajemen sumber daya manusia yang mutakhir menekankan bahwa penempatan tidak hanya berlaku bagi para pegawai baru akan tetapi berlaku pula bagi para pegawai lama yang mengalami alih tugas dan mutasi. Berarti konsep penempatan mencakup promosi, transfer dan bahkan demosi maupun pemutusan hubungan kerja.

5.

\section{Indikator Penempatan}

Dalam penempatan pegawai, tentunya perlu dipertimbangkan beberapa aspek sebelum pelaksanaan penempatan. Menurut Wahyudi (Yuniarsih \& Suwatno, 2013:117) dalam melakukan penempatan pegawai hendaknya mempertimbangkan faktorfaktor sebagai berikut:

a)

Pendidikan

Pendidikan yang harus dimiliki oleh seorang pegawai, pendidikan minimum yang disyaratkan meliputi: Pendidikan yang disyaratkan dan pendidikan alternative

b) Pengetahuan kerja
Pengetahuan yang yang harus dimiliki oleh seorang pegawai engan wajar yaitu pengetahuan kerja ini sebelum ditempatkan dan yang baru diperoleh pada waktu pegawai tersebut bekerja dalam pekerjaan tersebut.

c) Keterampilan kerja

Kecakapan atau keahlian untuk melakukan suatu pekerjaan yang harus diperoleh dalam praktek, keterampilan kerja ini dapat dikelompokan menjadi 3 (tiga) kategori yaitu : 1) Keterampilan mental, seperti menganalisa data, membuat keputusan dan lain-lain, 2) Keterampilan fisik, seperti membetulkan listrik, mekanik dan lain lain, 3) Keterampilan sosial, seperti mempengaruhi orang lain, menawarkan barang atau jasa dan lain-lain.

d) Pengalaman kerja

Pengalaman seorang pegawai untuk melakukan pekerjaan tertentu. Pengalman kerja dapat menjadi bahan pertimbangan untuk : Pekerjaan yang harus ditempatkan dan lamanya melakukan pekerjaan.

\section{B. Metode Penelitian}

Dalam penelitian ini penulis menggunakan metode deskriptif kualitatif, yang menguraikan dan memberikan gambaran secara sistematis, faktual, dan akurat dari obyek 
yang di teliti sehingga mendapat kebenaran.

Menurut Bogdan dan Taylor (2007 : 4) metode kualitatif adalah sebagai prosedur penlitian yang mengahasilkan data deskriptif berupa kata-kata tertulis atau lisan dari orang-orang dan perilaku yang diamati. Adapun obyek utama dalam penelitian ini adalah Evaluasi Penempatan Pegawai Pada Badan Kepegawaian dan Pengembangan Sumber Daya Manusia kabupaten Merauke. Penelitian ini dilaksanakan pada Badan Kepegawaian dan Pengembangan Sumber Daya Manusia kabupaten Merauke yang beralamat di Jalan Martadinata Kabupaten Merauke.

Informan dalam penelitian ini adalah Kepala Badan Kepegawaian dan Pengembangan Sumber Daya Manusia, Sekretaris Badan, Kepala Bagian dan Kepala Sub Bagian dimana menjadi sumber data yang bersifat utama karena mereka menjadi subjek dalam penelitian. Teknik analisa data dalam penelitian ini adalah analisis interaktif. Model ini ada 4 (empat) komponen analisis yaitu : pengumpulan data, reduksi data, penyajian data dan penarikan kesimpulan.

\section{Hasil Penelitian}

Para pegawai baru khususnya, yang telah selesai menjalankan program orientasi harus mendapatkan tempat pekerjaan yang sesuai dengan bakat dan keahlian yang dimilikinya. Salah satu fungsi manajamen sumber daya manusia (MSDM) untuk mengurus hal ini adalah placement atau penempatan pegawai. Penempatan pegawai berarti mengalokasikan pada pegawai pada posisi kerja tertentu, hal ini khusus terjadi pada pegawai baru. Kepada para pegawai lama yang telah menduduki jabatan atau pekerjaan termasuk sasaran fungsi penempatan pegawai dalam arti mempertahankan pada posisinya ataun memindahkan pada posisi yang lain.

Kegiatan penempatan pegawai dalam fungsi kepegawaian, dimulai setelah organisasi melaksanakan kegiatan penarikan dan seleksi, yaitu pada saat seorang calon pegawai di nyatakan diterima dan siap untuk ditempatkan pada jabatan atau unit kerja yang sesuai dengan kualifikasinya. Namun ternyata permasalahannya tidak sesederhana itu, karena justru keberhasilan dari keseluruhan program pengadaan tenaga kerja terletak pada ketepatan dalam menempatkan pegawai yang bersangkutan.

Dari hasil penelitian yang sudah dilakukan mengenai Penempatan pegawai sesuai kriteria evaluasi, penempatan pegawai sesuai prinsip 
penempatan dan tantangan dalam penempatan pada Badan Kepegawaian dan Pengembangan Sumber Daya Manusia Kabupaten Merauke maka akan dibahas dan dikaji lebih jauh dengan teori-teori yang digunakan dalam kerangka teori dalam penelitian ini, sebagai berikut :

\section{1.}

\section{Penempatan}

Pegawai

\section{Sesuai Kriteria Evaluasi}

Berdasarkan data penelitian diatas dinyatakan bahwa penempatan pegawai sesuai kriteria evaluasi pada Badan Kepegawaian dan Pengembangan Sumber Daya Manusia Kabupaten Merauke belum sepenuhnya optimal. Berikut akan dibahas penempatan pegawai sesuai kriteria evaluasi.

\section{a.}

Keefektifan

Hasil pemaparan penelitian manyatakan bahwa penempatan pegawai pada Badan Kepagawaian dan Pengembangan Sumber Daya Manusia Kabupaten Merauke belum sepenuhnya optimal, hal tersebut diperoleh melalui wawancara dengan metode wawancara dan observasi. Dimana hasil penelitian adalah penempatan pegawai belum sepenuhnya efektif, disebabkan proses penempatan adalah kewenangan Badan Kepegawaian Negara (BKN) berdasarkan data analisis kebutuhan pegawai yang disampaikan oleh Badan Kepegawaian dan
Pengembangan SDM Kabupaten Merauke, namun pada saat penempatan pegawai masih terdapat penempatan yang tidak sesuai dengan data analisis pegawai yang diusulkan, namun demikian Badan Kepegawaian dan Pengembangan SDM Kabupaten Merauke, tetap berusaha mengoptimalkan pegawai yang ada untuk bisa mencapai tujuan organisasi.

Menurut William Dunn (1998:611) keefektifan adalah : berkenaan dengan apakah suatu alternative mencapai hasil (akibat) yang diharapkan, atau mencapai tujuan dari diadakannya tindakan.

Pekasanaan penempatan pegawai dari krieteria keefektifan pada Badan Kepegawaian dan Pengembangan Sumber Daya Manusia Kabupaten Merauke belum efektif atau sesuai dengan pendapat William Dunn (1998:611).

\section{Penulis} juga menyimpulkan berdasarkan analisis penulis bahwa di Badan Kepegawaian dan Pengembangan Sumber Daya Manusia Kabupaten Merauke pada umumnya sudah berjalan efektif, namun ada beberapa kendala diantaranya : penempatan pegawai merupakan wewenang dari Badan Kepegawaian Negara (BKN) sehingga usulan yang diusulkan oleh Badan Kepegawaian dan 
Pengembangan Sumber Daya Manusia Kabupaten Merauke (BKPSDM) tidak sepenuhnya terpenuhi, namun kendala tersebut tidak terlalu mempengaruhi kinerja organisasi, hal ini dibuktikan dengan langkah atau kebijakan yang diambil oleh unsur pimpinan dalam menangani kendala tersebut.

b.

Keefisienan

Hasil penelitian manyatakan bahwa penempatan pegawai pada Badan Kepagawaian dan Pengembangan Sumber Daya Manusia Kabupaten Merauke belum sepenuhnya optimal, hal tersebut diperoleh melalui wawancara dengan metode wawancara dan observasi. Dimana hasil penelitian adalah penempatan pegawai belum sepenuhnya efisien, disebabkan proses penempatan adalah kewenangan Badan Kepegawaian Negara (BKN) berdasarkan data analisis kebutuhan pegawai yang disampaikan oleh Badan Kepegawaian dan Pengembangan SDM Kabupaten Merauke, namun pada saat penempatan pegawai masih terdapat penempatan yang tidak sesuai dengan data analisis pegawai yang diusulkan, namun demikian Badan Kepegawaian dan Pengembangan SDM Kabupaten Merauke, tetap berusaha mengoptimalkan pegawai yang ada dengan melakukan bimtek dan pelatihan
- pelatihan untuk bisa meningkatkan sumber daya para pegawai untuk mencapai tujuan organisasi.

Menurut William Dunn (1998:611) keefsienan adalah : berkenaan dengan jumlah usaha yang diperlukan untuk menghasilkan tingkat efektivitas tertentu.

Pekasanaan penempatan pegawai dari krieteria keefisienan pada Badan Kepegawaian dan Pengembangan Sumber Daya Manusia Kabupaten Merauke sudah efisien atau sesuai dengan pendapat William Dunn (1998:611).

Penulis juga menyatakan berdasarkan analisis penulis bahwa pada Badan Kepegawaian dan Pengembangan Sumber Daya Manusia Kabupaten Merauke, sudah bisa dikatakan efisien, apabila dikaitkan dengan teori yang digunakan dan analisi penulis selama di lapangan dikarenakan ada upaya untuk meningkatkan SDM para pegawai dengan pelaksanan BIMTEK dan pelatihanpelatihan yang dapat meningkatkan SDM pegawai agar dapat bekerja maksimal mendukung capaian tujuan organisasi.

\section{c. Ketanggapan}

Dari hasil penelitian manyatakan bahwa penempatan pegawai pada Badan Kepagawaian dan Pengembangan 
Sumber Daya Manusia Kabupaten

Merauke belum memperhatikan kriteria ketanggapan sehingga dapat dikatakan belum sepenuhnya optimal, hal tersebut diperoleh melalui wawancara dengan metode wawancara dan observasi.

\section{Menurut William Dunn (1998:611)} ketanggapan adalah : berkenaan dengan seberapa jauh suatu kebijakan dapat memuaskan kebutuhan, preferensi atau nilai masyarakat.

Pekasanaan penempatan pegawai dari krieteria ketanggapan pada Badan Kepegawaian dan Pengembangan Sumber Daya Manusia Kabupaten Merauke ketanggapan belum optimal sesuai dengan pendapat William Dunn (1998:611).

Penulis menyatakan berdasarkan analisis penulis bahwa belum sepenuhnya pegawai tanggap dengan tugas yang diberikan dalam hal ini sikap inisiatif atau respon pegawai masih sangat rendah, sebagai contoh ada beberapa pegawai yang selalu menunggu di perintah dan kurang adanya insiatif dalam mengerjakan pekerjaan atau tugas yang menjadi tanggung jawab dari pegawai tersebut, namun hal ini tidak terlalu berpengaruh pada organisasi, karena ada juga pegawai lain yang respon dan tanggap dengan tugas - tugas sehingga bisa mengerjakan tugas tersebut, sehingga tidak mempengaruhi tujuan organisasi.

2.

Penempatan

Pegawai

\section{Sesuai Prinsip-Prinsip Penempatan}

a.

Prinsip The Right Man on

\section{The Right Place}

Dari hasil penelitian manyatakan bahwa penempatan pegawai sesuai prinsip the right man on the right place pada Badan Kepagawaian dan Pengembangan Sumber Daya Manusia Kabupaten Merauke belum memperhatikan prinsip tersebut sehingga dapat dikatakan belum sepenuhnya optimal, hal tersebut diperoleh melalui wawancara dengan metode wawancara dan observasi.

Menurut Suwatno (2003 : 13) prinsip the right man on the right place adalah : penempatan setiap orang dalam organisasi perlu didasarkan pada kemampuan, keahlian, pengalaman, serta pendidikan yang dimiliki oleh orang yang bersangkutan.

Pekasanaan penempatan pegawai sesuai prinsip the right man on the right place pada Badan Kepegawaian dan Pengembangan Sumber Daya Manusia Kabupaten Merauke belum optimal sesuai dengan pendapat Suwatno (2003 : 13).

Penulis juga menyatakan berdasarkan analisis penulis bahwa belum sepenuhnya prinsip the right man on the 
right place diterapkan, hal ini terkait dengan penempatan pegawai terutama pada level jabatan struktural dimana kewenangan untuk menentukan pejabat adalah kewenangan dari tim BAPERJAKAT yang diketuai oleh Sekretaris Daerah, sehingga penentuan pegawai yang menduduki jabatan tertentu bukanlah kewenangan Kepala Badan, namun demikian hal tersebut tidak terlalu berpengaruh pada capaian kinerja organisasi, karena ada langkah dan upaya yang dilakukan oleh Kepala Badan, dan juga pejabat yang ditunjuk untuk menduduki jabatan tersebut juga bisa dengan cepat menyesuiakan diri dengan tugas dan jabatan yang diemban, sehingga secara umum tidak terlalu mempengaruhi pencapaian tujuan organisasi pada Badan Kepegawaian dan Pengembangan Sumber Daya Manusia Kabupaten Merauke.

b. Prinsip Efisen dan Produktivitas Kerja

Dari hasil penelitian manyatakan bahwa penempatan pegawai sesuai prinsip efisien dan produktivitas kerja pada Badan Kepagawaian dan Pengembangan Sumber Daya Manusia Kabupaten Merauke sudah memperhatikan prinsip tersebut sehingga dapat dikatakan optimal, hal tersebut diperoleh melalui wawancara dengan metode wawancara dan observasi.

Menurut Suwatno (2003 : 13) prinsip efisien dan produktivitas kerja adalah : Prinsip ini merupakan kunci kearah tujuan perusahaan karena efisiensi dan produktifitas kerja harus dicapai dalam rangka mencapai tujuan perusahaan.

Pekasanaan penempatan pegawai sesuai prinsip efisien dan produktivitas kerja pada Badan Kepegawaian dan Pengembangan Sumber Daya Manusia Kabupaten Merauke optimal dan sesuai dengan pendapat Suwatno (2003 : 13). Penulis juga menyatakan berdasarkan analisis penulis bahwa prinsip efisien dan produktivitas kerja sudah diterapkan, hal ini dibuktikan dengan pencapaian kerja yang dilakukan oleh Badan Kepegawaian dan Pengembangan Sumber Daya Manusia Kabupaten Merauke sehingga dalam pencapaian tujuan organisasi dapat berjalan dengan optimal.

c. Prinsip Kesatuan Arah

Dari hasil penelitian manyatakan bahwa penempatan pegawai sesuai prinsip kesatuan arah kerja pada Badan Kepagawaian dan Pengembangan Sumber Daya Manusia Kabupaten Merauke sudah memperhatikan prinsip tersebut sehingga dapat dikatakan optimal, hal tersebut diperoleh melalui 
wawancara dengan metode wawancara dan observasi.

Menurut Suwatno (2003 : 13) prinsip kesatuan arah : Prinsip ini diterapkan dalam perusahaan terhadap setiap karyawan yang bekerja agar dapat melaksanakan tugas-tugas, dibutuhkan kesatuan arah, kesatuan pelaksaan tugas, sejalan dengan program dan rencana yang digariskan.

Pekasanaan penempatan pegawai sesuai prinsip kesatuan arah pada Badan Kepegawaian dan Pengembangan Sumber Daya Manusia Kabupaten Merauke optimal dan sesuai dengan pendapat Suwatno (2003 : 13).

Penulis juga menyatakan berdasarkan analisis penulis bahwa prinsip kesatuan arah sudah diterapkan, sehingga dalam pencapaian tujuan organisasi dapat berjalan dengan optimal, dimana program - program kerja sudah sejalan dan sesuai dengan rencana dalam rangka pencapaian tujuan organisasi, hal ini terlihat dengan penyusunan sasaran kinerja pegawai (SKP) yang merujuk pada rencana dan program organisasi.

\section{Tantangan Dalam}

\section{Penempatan}

Dalam penyelenggaraan pelayanan publik oleh pemerintah diharapkan berdasarkan kebijakan yang telah ditetapkan didalam perumusan kebijakan, dan perlu mendapat evaluasi. Dari hasil penelitian manyatakan bahwa tantangan dalam penempatan pegawai pada Badan Kepeagwaian dan Pengembangan Sumber Daya Manusia Kabupaten Merauke, masih terdapat beberapa Kendala diantaranya : konflik internal, PHK pada pegawai honorer/tenaga kontrak, cuti pegawai dan kematian pegawai yang dapat menjadi tantangan tersendiri dalam proses penempatan pegawai pada Badan Kepegawaian dan Pengembangan Sumber Daya Manusia Kabupaten Merauke.

Namun demikian unsur pimpinan pada Badan Kepegawaian dan Pengembangan Sumber Daya Manusia Kabupaten Merauke, mengambil langkah - langkah strategis untuk mengatasi tantangan tersebut, langkah-langkah yang diambil adalah dengan memanfaatkan SDM yang ada sehingga dapat dikatakan tantangan tersebut tidak berpengaruh pada proses penempatan pegawai secara internal, sehingga pencapaian tujuan organisasi dapat tercapai dan secara umum tidak mempengaruhi kinerja para pegawai.

Hal ini diperkuat dengan analisis penulis selama melakukan penelitian, dimana semua pekerjaan yang dikerjakan oleh para pegawai berjalan optimal dan 
apabila ada tantangan seperti : konflik internal, PHK pada pegawai honorer/tenaga kontrak, cuti pegawai dan kematian pegawai maka ada upaya dan langkah yang langsung ambil oleh unsur pimpinan dengan memanfaatkan SDM yang ada, dan juga proses pengakaderan yang dilakukan oleh unsur pimpinan pada Badan Kepegawaian dan Pengembangan Sumber Daya Manusia Kabupaten Merauke sudah berjalan dengan baik, sebagai contoh : apabila pada Bagian, Bidang atau Unsur lainnya mengalami kendala karena hal tersebut diatas maka, pegawai pada Bagian, Bidang atau Unsur lainnya dapat mengerjakan dan menyeleseaikan tugas atau pekerjaan tersebut, pengakaderan yang dilakukan bukan hanya pada Bagian atau Bidang tertentu namun pada keseluruhan pelaksanaan tugas yang menjadi tanggung jawab dari Badan Kepegawaian dan Pengembangan Sumber Daya Manusia, sehingga tantangan tersebut tidak terlalu berpengaruh pada pencapaian tujuan organisasi dalam rangka penyelesaian tugas dan tanggung jawab.

\section{E. Kesimpulan}

Berdasarkan temuan penulis dan pembahasan hasil penelitian diatas mengenai evaluasi penempatan pegawai pada Badan Kepegawaian dan
Pengembangan Sumber Daya Manusia Kabupaten Merauke, maka dapat ditarik kesimpulan sebagai berikut :

1. Penempatan pegawai sesuai kriteria evaluasi ( Keefektifan, Keefisienan, dan Ketanggapan ) pada Badan Kepegawaian dan Pengembangan Sumber Daya Manusia Kabupaten Merauke, belum sepenuhnya berjalan optimal, karena masih terdapat beberapa kendala di antaranya : penempatan pegawai merupakan wewenang dari Badan Kepegawaian Negara (BKN) sehingga usulan yang diusulkan oleh Badan Kepegawaian dan Pengembangan Sumber Daya Manusia Kabupaten Merauke (BKPSDM) tidak sepenuhnya terpenuhi dan ada beberapa pegawai yang selalu menunggu di perintah dan kurang adanya insiatif dalam mengerjakan pekerjaan atau tugas yang menjadi tanggung jawab dari pegawai tersebut, namun kendala tersebut tidak berpengaruh signifikan pada proses pelaksanaan tugas dan fungsi dan kendala tersebut bisa diatasi dengan beberapa solusi, sehingga roda organisasi bisa berjalan cukup optimal.

2. Penempatan pegawai sesuai prinsip-prinsip penempatan (prinsip the right man on the right place, prinsip efisien dan produktivitas kerja dan prinsip kesatuan arah) belum 
sepenuhnya optimal karena penempatan pegawai terutama pada level jabatan struktural dimana kewenangan untuk menentukan pejabat adalah kewenangan dari tim BAPERJAKAT yang diketuai oleh Sekretaris Daerah, sehingga penentuan pegawai yang menduduki jabatan tertentu bukanlah kewenangan Kepala Badan, namun ada langkah-langkah strategis yang diambil oleh Kepala Badan Kepegawaian dan Pengembangan Sumber Daya Manusia Kabupaten Merauke, sehingga tidak berdampak signifikan pada pelaksanaan dan pencapaian tujuan organisasi.

3. Ada beberapa tantangan penempatan pegawai pada Badan Kepegawaian dan Pengembangan Sumber Daya Manusia Kabupaten Merauke diantaranya : konflik internal, PHK pada pegawai honorer/tenaga kontrak, cuti pegawai dan kematian pegawai yang dapat menjadi tantangan tersendiri dalam proses penempatan pegawai pada Badan Kepegawaian dan Pengembangan Sumber Daya Manusia Kabupaten Merauke namun tantangan itu diambil dengan bijak oleh pimpinan dengan memnafaatkan SDM yang ada sehingga tidak begitu mempengaruhi kinerja pegawai dalam mencapai tujuan organisasi.

\section{F. Daftar Pustaka}

Buku - Buku

Badjuri, Abdulkahar, dan Teguh Yuwono. (2002). Kebijakan Publik: Konsep dan Strategi. Semarang: Universitas Diponegoro.

Deddy Mulyadi, (2015). Studi Kebijakan Publik Dan Pelayanan Publik. Bandung, Alfa Beta.

Dunn, William N. (1998). Analisis Kebijakan Publik. Jakarta, Gramedia.

Handoko, T. Hani. 2008. Manajemen. Yogyakarta: BPFE.

Hasibuan, Malayu S. P. (2008). Manajemen Sumber Daya Manusia. Jakarta, PT. Bumi Aksara.

Hendry Simamora, (1995). Manajemen Sumber Daya Manusia ${ }_{\llcorner}$Jakarta, Karunika

Lexy J. Moleong. (2004). Metode Penelitian Kualitatif. Bandung : Remaja Rosda Karya.

Matthew B. Miles and Michael Huberman. (1992). Analisis Data Kualitatif. Jakarta : Universitas Indonesia.

Mathis and Jackson, (2006). Manajemen Sumber Daya Manusia. Jakarta, Salemba Empat.

Nugroho, Riant. (2006). Kebijakan Publik untuk Negara Berkembang. 
Jakarta: PT Elex Media

Komputindo.

Said Zainal . (2004). Kebijakan Publik. Jakarta, Pancur Siwa.

Santosa, (1998). Analisis Kebijakan

Publik. Jakarta, Sinar Grafika.

Sedarmayanti, (2001). Sumber Daya

Manusia dan Produktivitas Kerja, Jakarta, Ghalia Indonesia.

Setiyono, Budi. (2012). Birokrasi dalam Perspektif Politik \& Administrasi. Bandung: Nuansa Cendekia.

Siagian. (1996). Manajemen Sumber daya Manusia. Jakarta: Bumi Aksara

Subarsono. (2012). Analisis Kebijakan Publik. Yogyakarta: Pustaka Belajar.

Sugiyono. (2009). Metode Penelitian Kualitatif, Kuantitatf, dan $R \& D$. Bandung: Alfabeta.

Sugiyono, (2003). Metode Penelitian Administrasi, Bandung, Alfa Beta Surbakti, Ramlan. (1992). Memahami Ilmu Politik. Jakarta: PT Gramedia Widiasarana Indonesia.

Tangkilisan, Hessel Nogi S. (2005). Manajemen Publik. Jakarta: Grasindo

Thoha, Miftah. (1983). Administrasi Kepegawaian Daerah. Yogyakarta : Ghalia Indonesia.
Thoha, Miftah. (2011). Birokrasi dan Politik di Indonesia. Jakarta: Rajawali Pers.

Wibawa, Samudra. (2011). Politik Perumusan Kebijakan Publik. Yogyakarta: Graha Ilmu.

Winarno, Budi. (2008). Kebijakan Publik: Teori dan Proses. Yogyakarta: Media Pressindo.

\section{Dokumen}

Undang - Undang Nomor 5 Tahun 2014 Tentang Aparatur Sipil Negara $(\mathrm{ASN})$

\section{Jurnal dan Tesis}

Petrus Mbaraka, (2016). Analisis Kinerja Aparatur Pada Badan Kepegawaian Pendidikan dan Pelatihan Kabupaten Merauke, Tesis. Jayapura : Program

Pasca Sarjana Program Studi Magister Ilmu Administrasi Publik, Universitas Cenderawasih. 